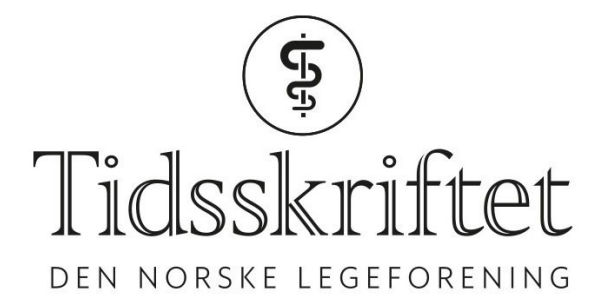

\title{
Slik sukret tobakksindustrien barnas hverdag
}

FRA ANDRE TIDSSKRIFTER

KETIL SLAGSTAD

E-post: ketil.slagstad@medisin.uio.no Institutt for helse og samfunn

Universitetet i Oslo

Amerikansk tobakksindustri har målrettet utviklet og markedsført brus mot barn.

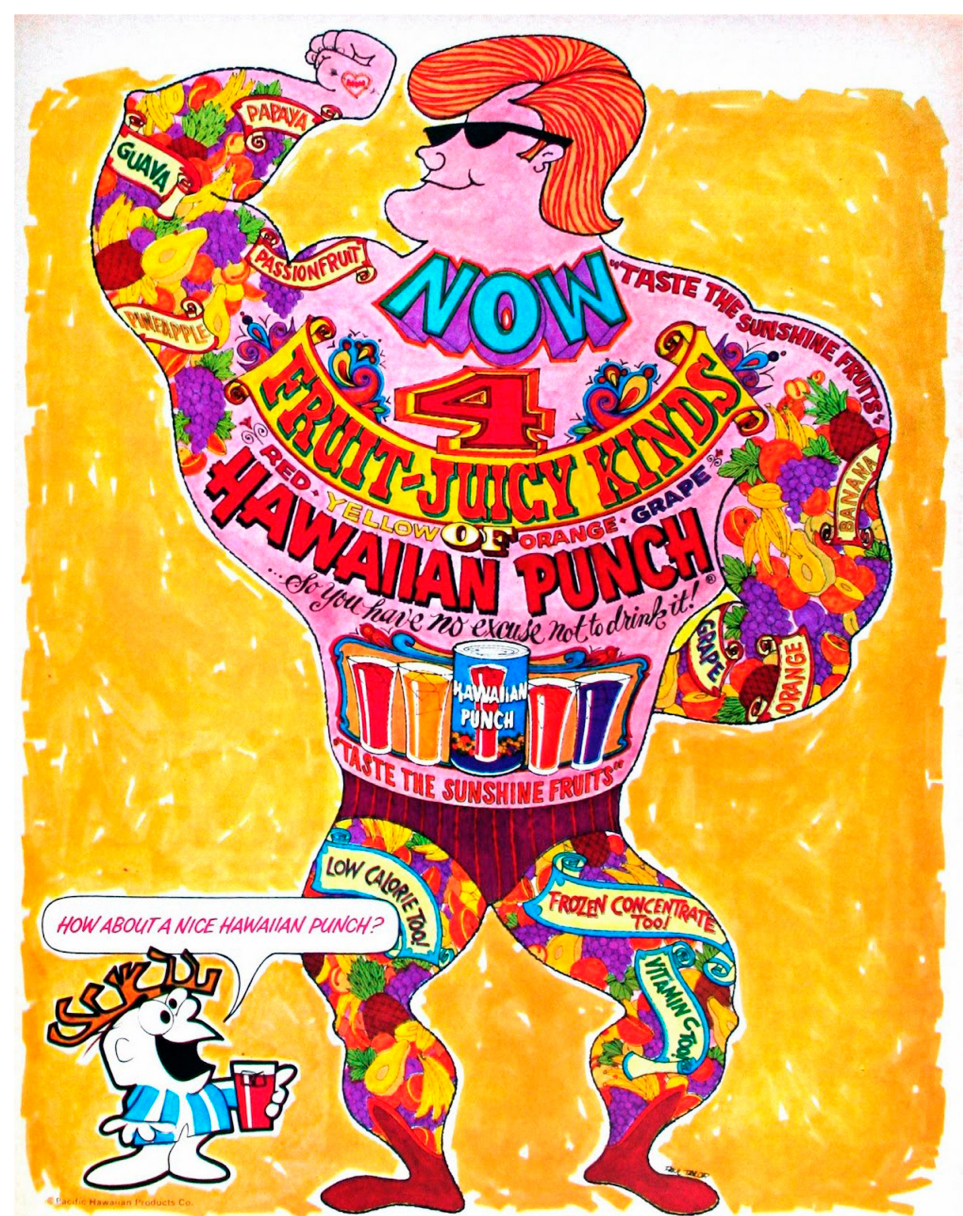

Reklame for Hawaiian Punch fra 196o-årene. Illustrasjonsfoto: The Advertising Archives / Alamy Stock Photo

De to største tobakksprodusentene i USA, R.J. Reynolds og Philip Morris, begynte i 196oårene å kjøpe opp brusmerker. Deretter brukte de markedsføringsekspertisen de hadde 
bygd opp på tobakksprodukter, på leskedrikker rettet mot barn. Det viser en ny studie publisert i BMJ. Studien er basert på historiske dokumenter fra tobakksindustrien som omhandler blant annet markedsføring, strategier og forskning (1). Over 10 ooo dokumenter ble først identifisert ved at artikkelforfatterne brukte søkeord som «soft drink» og merkenavn på sukkerholdige drikkevarer, før de brukte den såkalte snøballmetoden for å identifisere andre relevante dokumenter.

Studien viser hvordan tobakksindustrien målrettet gikk etter barn i utviklingen av produkter: brusetabletter, brus på rørepinner og smaker som barn foretrakk. Drikken Hawaiian Punch gikk med Reynolds' kreative markedsføring fra å være en cocktailmiks for voksne til å bli en leskedrikk for barn. For å tilpasse produktet til barn utviklet firmaet maskoten Punchy til TV-reklame, klær, leker og skolebøker. Innpakningene ble tilpasset barn ved å gå fra store husholdningsflasker til nette, håndholdte bokser med sugerør. Philip Morris samarbeidet på sin side med bl.a. Mattel og Nintendo for å lage leker med leskedrikken Kool-Aid, for eksempel Barbie-dukker som solgte brus på stand. Firmaets underselskap Kraft Foods kjøpte i 1991 rettighetene til drikken Capri Sun. Fruktdrikken, som kom i små aluminiumsposer med sugerør, ble markedsført mot barn i alderen 6-14 år som en «helt naturlig drikk for barn i en kul pose». Senere ble drikken inkludert i «lunsjboksen» Lunchables, et produkt rettet mot travle husmødre som skulle spare tid når skolematen skulle pakkes om morgenen.

Studien viser hvor kreativt - og kynisk - tobakksindustrien har jobbet for å markedsføre sukkerholdige drikker mot barn. Reklame for sukkerholdige produkter rettet mot barn må forbys gjennom internasjonale avtaler.

\section{LITTERATUR:}

1. Nguyen KH, Glantz SA, Palmer CN et al. Tobacco industry involvement in children's sugary drinks market. BMJ 2019;364: 1736. [PubMed][CrossRef]

Publisert: 18. juni 2019. Tidsskr Nor Legeforen. DOI:10.4045/tidsskr.19.0334

(C) Tidsskrift for Den norske legeforening 2020. Lastet ned fra tidsskriftet.no 